\title{
Albert Ross Tilley: The legacy of a Canadian plastic surgeon
}

\author{
Kevin Mowbrey BMSc
}

\begin{abstract}
K Mowbrey. Albert Ross Tilley: The legacy of a Canadian plastic surgeon. Can J Plast Surg 2013;21(2):102-106.

The present article chronicles the career of Dr Albert Ross Tilley, one of the most important Canadian plastic surgeons of the 20th century. Tilley is most well known for his innovations of burn management during World War II and his treatment of a group of burn patients known affectionately as the 'Guinea Pig Club'. In addition to the superb surgical skills he applied to the physical wounds of his patients, Tilley was also a pioneer of caring for the emotional and psychological afflictions suffered by many airmen of World War II. As one of the founding fathers of the Canadian Society of Plastic Surgeons, Tilley's work was instrumental in establishing the specialty and ensured its prosperity for years to come. Serving in the capacity of leader, educator and innovator, Tilley remains one of Canada's most decorated physicians, and his body of work encompasses contributions to the medical field that remain significant and beneficial to patient care to this day.
\end{abstract}

Key Words: Burn management; East Grinstead; Plastic surgery; Ross Tilley; The Guinea Pig Club; WWII

\author{
Albert Ross Tilley : l'héritage d'un plasticien \\ canadien
}

Le présent article relate la carrière d'Albert Ross Tilley, l'un des plasticiens canadiens les plus importants du XXe siècle. Il est réputé pour ses innovations dans la prise en charge des brûlures pendant la Deuxième Guerre mondiale et pour le traitement d'un groupe de patients brûlés connu affectueusement sous le nom de "club des cobayes ». Outre les remarquables compétences chirurgicales qu'il utilisait pour soigner les plaies de ses patients, le docteur Tilley était également un pionnier des soins des problèmes affectifs et psychologiques dont ont souffert de nombreux pilotes de la Deuxième Guerre mondiale. Le docteur Tilley est l'un des fondateurs de la Société canadienne des chirurgiens plasticiens, et par ses travaux, il a contribué à établir la spécialité et à en garantir la prospérité pendant des années. Leader, formateur et innovateur, le docteur Tilley demeure l'un des médecins canadiens les plus décorés, et encore aujourd'hui, son apport à la médecine demeure important et bénéfique pour les soins aux patients.

\begin{abstract}
$\Delta$ s one of the first plastic surgeons in Canada, Dr Albert Ross Tilley A (Figure 1) would ultimately be responsible for shaping much of the discipline's foundation and, to this end, he assumed the role of innovator, healer, leader and teacher. The trajectory of Tilley's career not only influenced the inertia of a young burgeoning specialty but also the young practitioners who aspired to be a part of the profession. Dr Tilley was an innovator of burn management in the wake of a war that threatened to incinerate all who engaged in battle. He was the healer of an affliction that society was ill-equipped to handle, and the medicine Tilley would dispense for this ailment would indelibly alter the landscape of patient care forever. As a leader, Tilley's efforts imbued respect and authority into a profession that was initially viewed with scoff and disdain. With prophetic foresight, Dr Tilley understood the value of teaching and took to the task with great patience and enthusiasm. Dr Tilley's body of work has a paradoxical resonance, seeming at once to set the bar of professional achievement insurmountably high, but at the same time inspiring those who read of his labours to strive for a comparable level of excellence.
\end{abstract}

\section{TILLEY'S BACKGROUND}

Albert Ross Tilley was born in Bowmanville, Ontario, on November 24, 1904 (1). As the son of a general practitioner, Tilley's interest in medicine was piqued at an early age because he had the privilege of accompanying his father while they rounded on patients throughout town. At the University of Toronto (Toronto, Ontario), Tilley proved himself as both a talented athlete, competing on the swim and water polo teams as a silver medalist, and a superb student, graduating from medical school in 1929 (2). Following medical school, Tilley travelled extensively for five years, studying surgery at the Toronto Western Hospital (Toronto, Ontario), the Roosevelt and Bellevue Hospitals in New York (USA), The Royal Infirmary of Edinburgh in Scotland and with the renowned pathologist Sternberg in Vienna, Austria (2). By

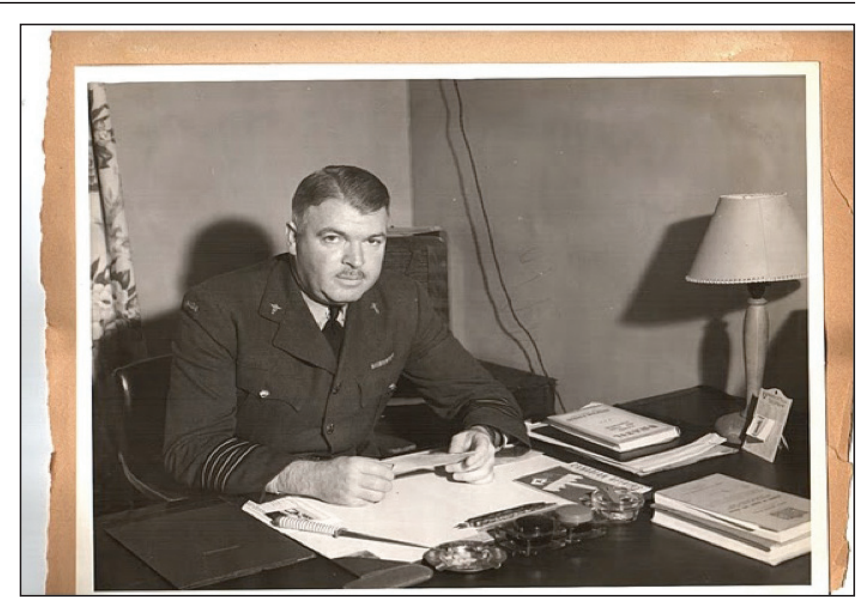

Figure 1) Dr Albert Ross Tilley

1935, Tilley was ready to open a private practice working at the Wellesley and Toronto Western Hospitals.

In the same year, Tilley joined the No. 400 City of Toronto Squadron of the Royal Canadian Air Force (RCAF) as a medical officer and began what would ultimately be the most important training of his career (2). Dr E Fulton Risdon, a protégé of Sir Harold Gillies and widely regarded as the father of modern plastic surgery in Canada, was to guide Tilley's focused training in plastic surgery. At this point in history, Dr Risdon was one of only three other plastic surgeons in Canada, with Tilley becoming the fourth on the completion of his training just before the outbreak of World War II (WWII) (3). Tilley was called to active service in 1939 and, by 1940, found himself a commanding officer and C Surgeon at Trenton Memorial Hospital

Faculty of Medicine and Dentistry, University of Alberta, Edmonton, Alberta

Correspondence: Kevin Mowbrey, 1435 Herring Cooper Way, Edmonton, Alberta T6R 2L9. Telephone 780-435-2361,

fax780-435-2361,e-mail kmowbrey@ualberta.ca 
(Trenton, Ontario) (3). A year later, he was appointed principal medical officer at the RCAF headquarters in London, England. Shortly after arriving in London, Tilley received a life-altering invitation, the acceptance of which would set into motion a chain of events that literally changed the faces of hundreds of airmen burned in WWII. Equipped with his newly honed skills in plastic surgery, Dr Tilley travelled to the Queen Victoria Hospital in East Grinstead, Sussex, in January 1942 (1). He would be charged with the task of treating the most difficult burn injuries wrought from the pyre of war.

\section{FATES WORSE THAN DEATH: BURN CASUALTIES OF WWII}

History has frequently proven that no man achieves greatness irrespective of the context surrounding him, but rather, it is achieved when the opportunity for greatness produced by a confluence of events is pounced on. One such event that would push Tilley's skills to their very limit was the nature of burn casualties in WWII. It is entirely reasonable to assume that being caught in the cross-hairs of a Nazi pilot was the worst nightmare of every allied airman, but this would not be completely accurate. The entity that struck unadulterated fear into the heart of the RCAF was fire. Referred to by nicknames, such as 'orange death', the threat of burning alive was an unrelenting terror, and many pilots openly admitted that gravity or a bullet was a welcome alternative (4).

On allied aircraft, whether 'Spitfire' or 'Hurricane', the vector carrying the combustible arch nemesis of airmen was the fuel tank (5). Due to its vulnerability, a solution in the form of a system of self-sealing layers was developed and refined by the Allies. The concept behind this solution was that wrapping the fuel tank in a series of elastic materials would reduce the velocity of projectiles impacting the tank, thereby preventing ignition (4). Furthermore, materials were selected and designed in such a way that when they were penetrated, they would respond by stretching and swelling to self-seal and prevent fuel leakage from the ruptures. Examples of materials tested and used in these selfsealing systems included fabric treated with flame-retardant chemicals, rubber, felt and iron gauze (4). All of the resources invested into developing an effective fuel tank protection system eventually paid off; however, the solution was not without cost.

During the interwar period, the Royal Air Force (RAF) conceived new and ambitious strategies for air warfare of the future. In the eyes of the RAF, the victor of this new strain of combat would be seated in aircraft of unprecedented speed and armament capacity (6). Unfortunately, the demands of this strategy pitted fuel tank safety against parameters of performance. To produce planes that could outfly and outshoot the competition, drastic changes in aeronautical design were necessary, including upgrading the 87 -octane fuel used in the Great War to the more combustible 100-octane fuel (7). Furthermore, to achieve the highly sought after rapid rate of ascent, the necessary design required positioning of the fuel tanks directly below and in front of the cockpit. In essence, the pilot would find himself sitting on approximately $320 \mathrm{~L}$ of fuel in the Spitfire and $130 \mathrm{~L}$ of fuel in the Hurricane (5). The problem with implementing the tank protection system of rubber and metal encasements was that the materials added nearly $50 \mathrm{~kg}$ to the plane's weight. This burden turned out to cut the maximum range of fighter planes by nearly $20 \%$ - a sacrifice in performance that top officials of the RAF were unwilling to accept (4). Ultimately, strategy took priority over safety and pilots were left to rely on their tactical skill to avoid the potential inferno sloshing around below them. To the dismay of hundreds of airmen, this tactical skill, however formidable, would not prove enough and many sustained burns that rendered them unrecognizable.

It is estimated that between 1940 and 1945, 22,000 soldiers burned to death and 4500 burn victims were recovered from crashes, with $60 \%$ to $80 \%$ of those rescued sustaining burns to their hands and face (8). This scale of burn casualties had never before been witnessed and was not predicted by allied strategists. A certain pattern of burn injury presented so frequently to hospitals that it was given its own designation. 'Airman's burn' was described in numerous wartime medical texts as "a burn of almost unwavering characteristics due to the sudden exposure of unprotected parts of the body to intense dry heat or flame, as though the patient were thrust into a furnace for a few seconds and withdrawn", the product of which was "deep, searing burns, usually of third degree to areas of tremendous functional importance - the hands and eyelids in particular" (9). The position of the fuel tank often resulted in its contents exploding in the face of the pilot, which accounts for the characteristic facial burns sustained. In addition to the hands and face, airmen commonly experienced burns to their wrists, neck, thighs and scalp (10).

The obligation of the RAF and RCAF to commit whatever resources necessary to ensure the best treatment possible for its burned airmen consisted of two components. First, these young men had volunteered to fight in the service of protecting their country, and the nation indebted to these heroes demanded they receive care of the utmost quality. Second, pilots were an invaluable resource in the air campaign, especially during the Battle of Britain. During autumn 1940 , a commodity more critical to victory than steel or oil, and in rapidly diminishing supply, was experienced pilots with masterful ability won through hard-fought battles (6). Burn injuries served to remove airmen from combat for weeks to months at a time; therefore, the RAF needed to rehabilitate its most valuable resource as quickly as possible under the threat of an air campaign failure. From the skies of WWII rained showers of blazing metal and charred flesh, and when these tokens of chaos reached earth, they lay smoking on the ground, viewed with panicked perplexity by those tasked with treating them. Luckily for the multitude of victims, there were men willing and able to set themselves to the task of rehabilitating these heroes who had sacrificed a pound of flesh for the good of their country.

\section{TOUGH AS LEATHER: BURN MANAGEMENT BEFORE WWII}

Shortly after arriving at East Grinstead, it became abundantly apparent to Tilley that the increasing number of Canadian burn casualties flooding the hospital would need their own ward. Under Tilley's planning and leadership as the newly appointed chief surgeon and commanding officer, Royal Canadian engineers prepared to erect a 50-bed wing that would cost $\$ 80,000$ and take one year to build (2-4). On its completion in 1944, the Canadian wing had a staff of more than 50, including orderlies, specialist nurses and clerks (Figure 2). The answer to the query of why the RCAF and RAF were not prepared at the outset of the war to receive this scale of burn casualties rests in the development of burn management before 1939 .

For decades before WWII, patients with severe burns were deemed terminal and the standard of care consisted of administering minute amounts of saline, a gargantuan dose of morphine and orders for the patient to return home so they could be surrounded by their loved ones as death swiftly followed (11). Burn patients were scarcely encountered in teaching hospitals because their cases were viewed as hopeless and admission rarely occurred. The reason that major burns rapidly killed nearly everyone sustaining them was shock and the inability of the medical profession to administer effective treatment to halt its progression (8). Severe burns would initiate a chain reaction of events beginning with massive fluid loss from the wound, followed by shock and the successive failure of multiple organ systems until the patient was no longer able to cling to life. If by some divine intervention the patient persevered through the shock, the next hurdle to their recovery was infection. With odds stacked so highly against recovery from severe burns, the treatments that developed were largely chemical interventions geared toward minor burns, with surgical involvement a rare occurrence (10). Breakthroughs in treating shock changed everything.

The 1920s gave witness to physicians tinkering with the idea of fluid resuscitation, but out of fear of unknown adverse effects, they never dared to give fluid in the amounts necessary to stem the tide of shock (8). It was not until the 1930s that saline and plasma 


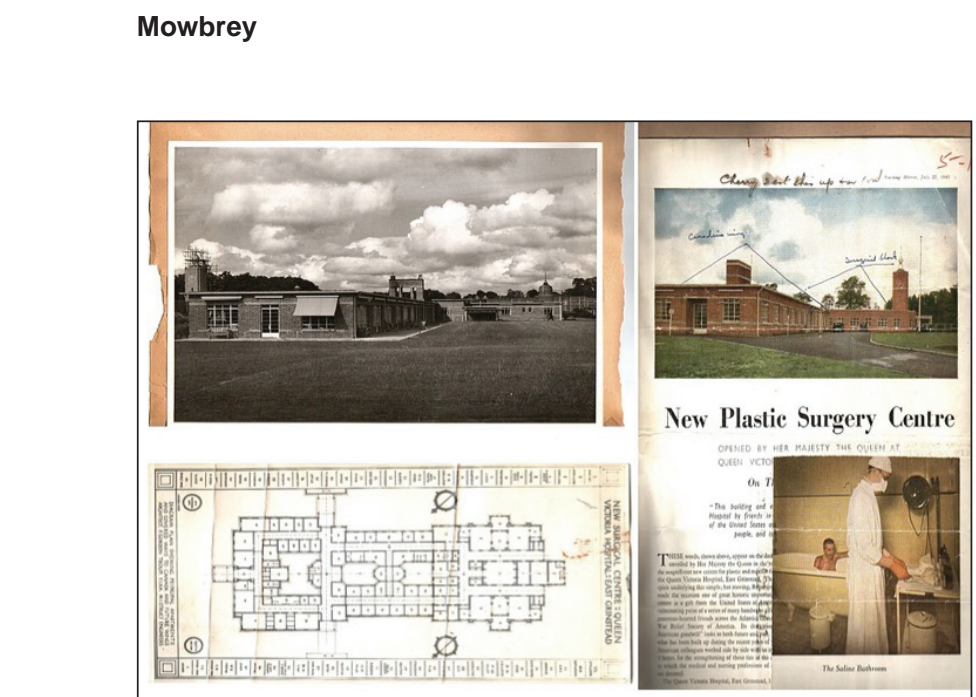

Figure 2) Queen Victoria Hospital at East Grinstead, England (top left). Schematic of Queen Victoria Hospital (bottom left). Image from an article of unknown source regarding the opening of the new Canadian wing and Queen Victoria Hospital (right)

transfusions were gradually being administered in ever-increasing volumes. Eventually, the treatment of shock had evolved to such an extent that the majority of severe burns - traditionally viewed as death sentences - no longer produced corpses for coffins, but extremely complicated patients requiring specialized, multifaceted care (4). The advances in shock therapy inadvertently created a new patient population that needed treatment desperately. The physicians of the day did the only thing they could, and used the tools with which the medical atmosphere of the era had equipped them; the results proved unacceptable to physicians such as Tilley.

When the first wave of severely burned airmen started to arrive, the major treatment method used was centred around coagulation. A coagulating agent would be applied to the burn that caused a tough hide of scab-like tissue to encase the wound (10). This functioned as a chemical dressing of sorts, and was believed to be advantageous by many physicians in its ability to protect the wound, prevent lifethreatening fluid loss and guard against sepsis (8). The coagulant that was administered nearly universally was tannic acid (12). The very same substance used in the leather industry to stiffen hides became the treatment applied to the burns of pilots shot down all over Europe. Metal tubes of tannic acid were so widely distributed that at the outset of the war, they could be found in almost every emergency room, medic bag and first-aid kit in allied territory. In theory, coagulation therapy served both as immediate first-aid as well as a long-term treatment that remained in place until new tissue had grown underneath, after which the coagulum could be removed (13). The reality of treating airmen's burns with tannic acid turned out to be so disastrous that it prompted one of Tilley's mentors at the Queen Victoria Hospital, the great Sir Archibald McIndoe, to undertake a crusade against its continued use.

The problems with treating airmen's burn with coagulation therapy proved numerous. Tannic acid applied to burns of the hands resulted in stiffness to the point of complete immobility (14). In addition to stiffness, the thick hide of coagulated tissue exacerbated edema and constricted an already diminished circulation. This compression of blood flow in the hands frequently resulted in ischemia, necrosis and the loss of fingers (14). The black eschar also made it very difficult for the medical staff to detect infections, which often went unrecognized until the indicative aroma wafted into the nostrils of patient and staff. With the goal of avoiding septicemia, the coagulum was ripped from the wound so antiseptic agents could be administered, but this commonly proved ineffective and agonizingly painful for the patient (10). Results of coagulants applied to burns of the face were equally distressing. Gentian violet was used for facial burns due to the belief

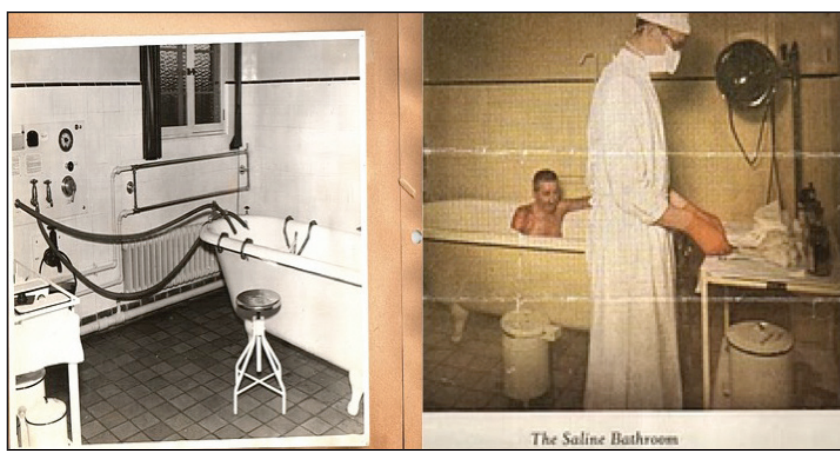

Figure 3) Saline bath at Queen Victoria Hospital at East Grinstead, Sussex, England

that it was more 'delicate' than tannic acid (15). Despite its purported virtue, gentian violet left facial tissue rigid, and eyelids so taut that the patient often suffered corneal scratches or ulceration from being unable to blink (15). If lucky enough to avoid irrevocable blindness during the gentian treatments, the patient then had to worry about the subsequent scarring that often everted the eyelids. Setting aside their immediate harm, the long-term hindrance posed by coagulation therapy was that it completely obliterated viable grafting surfaces. Once the coagulum was removed, its place was taken by thick spindles of keloid scarring, the likes of which vapourized hope for any degree of reconstruction (15). Fortunately, for the hundreds of patients who would experience burns to the hands and face, McIndoe (16) was able to persuade the majority of his colleagues - and the scientific community at large - that the heinous results of tannic acid justified the banishment of its use across Europe.

\section{PULLED FROM THE FURNACE:}

\section{TILLEY'S APPROACH TO BURN MANAGEMENT}

With coagulation therapy for third-degree burns of the hands and face effectively banned thanks to the advocacy of McIndoe, the challenge of implementing an efficacious treatment regimen for severe burns loomed over the wards of East Grinstead. The approach cultivated by McIndoe and Tilley at the Queen Victoria Hospital, which served as the prototype for burn management and was duplicated at centres across Europe, consisted of three vital components (4). To preserve surfaces viable for grafting, atraumatic dressings were essential. The form of dressing most commonly used consisted of a single layer of tulle gras placed directly on the surface of the wound, followed by a sterile saline compress over top (14). The benefits of this method became apparent anytime staff needed to remove the dressings to clean the wound or examine it for signs of infection; the tulle gras could be changed easily without inciting any additional trauma at the burn site.

The second pillar of burn management Tilley used was the saline bath (Figure 3). Ablution was viewed as a critical method in maintaining clean, healthy wounds as well as being instrumental in the granulation process (14). In addition to fostering a viable grafting surface, saline baths also enabled patients to keep their wounds flexible. This was especially important for burned hands, which were much more mobile under water and proved quite favourable for circulation and the salvaging of the greatest proportion of digits possible (16). Patients under Tilley's care would soak for $1 \mathrm{~h}$ in tubs of saline two to three times per day, during which time, dressings would seamlessly float off the burn site and save the patient from the potential agony of removing them under dry conditions (10).

To achieve a truly successful treatment regimen, Tilley's management of burns also had to neutralize infections. 'Sulphanamide dusting' was one strategy used, in which a powder form was gently sprinkled over the surfaces of burns (14). For burns of the hand, plastic bags filled with powdered sulphanamide encasing the injured limb were believed to be effective measures against sepsis (14). It had also come 


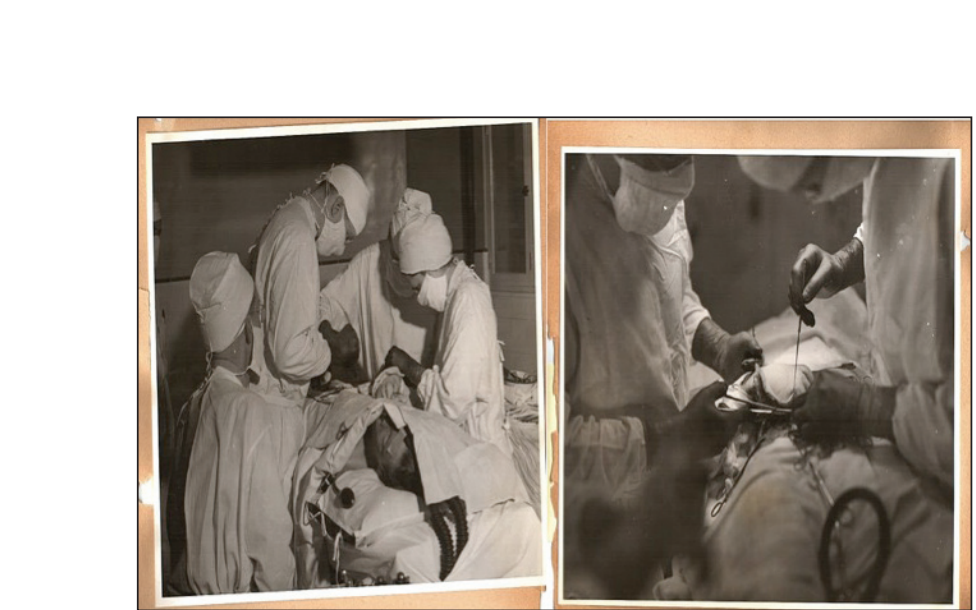

Figure 4) Surgery at the Queen Victoria Hospital at East Grinstead, Sussex, England

to light that the wool blankets found in hospitals harboured and transmitted infections to scores of patients across Europe; therefore, Tilley had them exchanged with layered linens. One of the more 'radical innovations' used at Queen Victoria Hospital was to ensure physical separation of the burn unit from other wards of the hospital, which broke with the convention of burn patients interspersed throughout various wards (4). This served to cut the rampant infection rates produced by cross-contamination among different patient groups that had plagued hospitals in the past. Patients at highest risk were those with burn wounds and jaw injuries, who were housed in special isolation units.

With the sulphanamide-tulle gras-saline sequence producing patients whose burns remained conducive to subsequent reconstructive therapy, Tilley set himself to the task of restoring the hands and faces his patients had lost (Figure 4). One of Tilley's first objectives was to reconstruct the ears of his patients; without them, he would ask, "how could a man hold his glasses on?" (3). Most men would need between 10 and 50 operations, requiring them to be in and out of the hospital for at least three years. It was customary to plan eight surgeries per year, alternating three to four weeks in hospital with two- to threeweek breaks outside (10). Whereas acromiothoracic flaps were used for deep unilateral burns, in cases where adequate free grafts were consistently produced, patients were treated in this way entirely (8). During his tenure at Queen Victoria hospital, Tilley would replace countless noses, reform a multitude of ears and eyelids, and re-establish a plethora of facial features, all with the objective of giving his patients the chance to return to a normal state of existence. However, Tilley's operative virtuosity was not all that he offered his patients.

\section{A SCALPEL, A GUINEA PIG AND A TENDER HAND: TILLEY'S APPROACH TO THE PATIENT RELATIONSHIP}

By 1944, the Canadian wing at Queen Victoria Hospital opened and Tilley was promoted to the rank of group captain. In June of the same year, Tilley found himself standing in front of King George VI at Buckingham Palace with the Order of the British Empire being bestowed on him (1). This prestigious award was fitting recognition of Tilley's success in Britain and, along with the work of McIndoe and the hospital staff, they had become "the most formidable and effective response to burn injuries, anywhere in the world" (4).

The work at Queen Victoria Hospital was so groundbreaking that it brought one patient to remark in jest "We're nothing but a bunch of damn guinea pigs!" bringing into existence one of the most critical components of burn rehabilitation during WWII: 'The Guinea Pig Club' (17). The Guinea Pig Club was formed in 1941 by a group of airmen who had suffered burn injuries in the war and were subsequently treated at the Queen Victoria Hospital. Consisting of nearly 650 members of a dozen different nationalities, the club was one of the first support groups in medical history (17). The camaraderie and sense

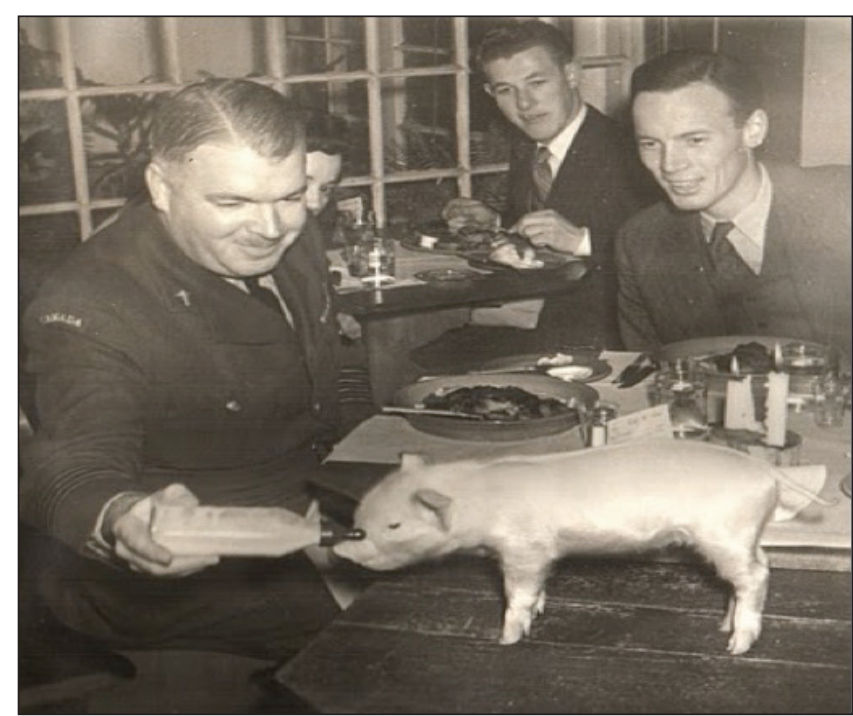

Figure 5) Albert Ross Tilley poses for a photograph symbolizing the care he gave to his real patients, the 'Guinea Pigs'

of belonging fostered by the club has been acknowledged by many historians as instrumental in bolstering the morale of its members, and in the therapeutic success ultimately achieved at East Grinstead (4). The Guinea Pig Club became an entity that shielded patients from suffering their disfigurement in isolation. As a symbol of their indomitable resolve to move forward with heads held high, the club gave its members the strength to carry on, to venture out into the world, and to walk the streets wearing their wounds as testaments of their sacrifice and commitment to protecting their nation. With more than 200 Canadian Guinea Pigs under his care, Tilley served as president of the Canadian branch, and would be operating on its members for the next 40 years (Figure 5) (3).

In addition to his operative prowess, Tilley also dedicated a tremendous amount of personal attention to the emotional and psychological condition of his patients. After operating all day and into the evening, Tilley would rest briefly in his living quarters only to make his way back to the hospital at 23:00 to check how his patients were faring after their surgeries (4). In a medical landscape dominated by rampant paternalism, Tilley was a trailblazing pioneer of patient empowerment who went to great lengths to educate his patients about every aspect of their care, every nuance of their surgeries and the intricate details of what they could expect during recovery (18). Where many surgeons of the day saw their involvement in patient care beginning and ending in the operating room, Tilley was a fierce proponent of the importance of a patient's psychological well-being in their overall rehabilitation. In his care of the Guinea Pigs, Tilley transcended the customary duties of a physician and rose to become a shining light that illuminated a comprehensive path to recovery (18). For decades after the war, Guinea Pigs from across the world would come together for an annual celebration in which one of their toasts was always to the care they received from Tilley, unanimously described as far exceeding the normal call of duty. Out of respect, gratitude and appreciation for Tilley's commitment to them, the Guinea Pig Club funded a bronze bust of their treasured physician installed in the Canadian wing of the Queen Victoria Hospital; it sits as a token commemorating the man whose tender hand pulled them from the furnace (2).

\section{NO SIGN OF SLOWING DOWN:}

TILLEY'S LIFE AFTER THE WAR

On his return from Britain in 1945, Tilley became a consulting physician at Christie Street Hospital and Toronto Wellesley Hospital. For several years between 1949 and 1965, Tilley also spent three days every month in Kingston, Ontario, where he worked as a staff physician at the Hotel Dieu, Kingston General and Kingston Military Hospitals 
(2). As one of only 10 other plastic surgeons practicing in Canada after the war ended, Tilley was extremely busy laying the framework for the future of his specialty. His colleagues viewed him as a physician capable of breaking new ground. In July 1942, Tilley had led the first all-Canadian plastic surgery operation and, a few years later, as an assistant professor at Queen's University (Kingston, Ontario), he would be the first to offer formal accredited courses in the specialty (2). Between inventing several surgical instruments, such as an ingenious hand splint, and being the first to design the tube pedicle flap, Tilley even found the time to marry his beautiful Australian wife, Jean Russell, in $1952(19,20)$.

Tilley was one of the 12 founding fathers of the Canadian Society of Plastic Surgeons in 1947. At its second meeting on June 2, 1948, the Society's members empowered Tilley to draft a fee schedule for the operations performed most commonly by plastic surgeons (20). Appointed vice-president in 1953, then president in 1954, Tilley's leadership of The Canadian Society of Plastic Surgeons helped establish the profession in Canada and paved the way for the exponential growth and prosperity it would experience in subsequent years (20). As his specialty flourished across the country, Tilley continued to infuse his discipline with respect and integrity as he campaigned for years to develop burn treatment facilities in Ontario. In 1984, his vision came to fruition and the Ross Tilley Burn Centre opened at Wellesley Hospital (21). Only three years after becoming the first plastic surgeon to be appointed a member of the Order of Canada, Tilley also assumed the role of Founder and Director of the first adult burn centre in Canada $(19,21)$. Even after retiring from practice at Wellesley and Sunnybrook hospitals in 1981, Tilley would continue to be recognized for his outstanding career, having an elementary school in his hometown named in his honour and being inducted into Canada's Aviation Hall of Fame in 2006 (1,3). After dedicating much of his 84 years of life to his patients, Albert Ross Tilley passed away on April 19, 1988 (21).

\section{REFERENCES}

1. Albert Ross Tilley. Alberta: Canada's Aviation Hall of Fame; (C2011 [cited 2011 June 10]. < www.cahf.ca/members/T_members. php\#A.\%20Ross\%20Tilley> (Accessed July 15, 2012).

2. Gray C. Profile of A. Ross Tilley. Can Med Assoc J 1983;129:154.

3. Wilton P. WW II "guinea pigs" played crucial role in refining plastic surgery in Canada. CMAJ 1998;159:1158-9.

4. Mayhew ER. The Reconstruction of Warriors: Archibald McIndoe, the Royal Air Force, and the Guinea Pig Club, 1st edn. London: Greenhill Books, 2004.

5. Downing T, Johnston A. The Spitfire Legend. History Today 2000;50:19-25.

6. Keegan J. The Second World War, 1st edn. New York: Penguin Books, 1989.

7. Bailey G. The Narrow Margin of Criticality: The Question of the Supply of 100-Octane Fuel in the Battle of Britain. English Historical Review 2008;123:395-411.

8. Jackson DM. Burns: McIndoe's contribution and subsequent advances. Ann Royal Coll Surg Engl 1979;61:335-40.

9. McIndoe AH. Total reconstruction of the burned face. Br J Plast Surg 1983;36:410-20.

10. Geomelas M, Ghods M, Ring A, Ottomann C. "The Maestro": A pioneering plastic surgeon - Sir Archibald McIndoe and his innovating work on patients with burn injury during World War II. J Burn Care Res 2011;32:363-8.

\section{CONCLUSION}

The distinguished and illustrious career of Albert Ross Tilley exemplifies many of the qualities sought after by physicians today. As a surgeon, he is remembered for the meticulous technical skill, sound judgment and tireless work ethic he applied to rehabilitating the burned heroes placed under his care. He was a leader, innovator and educator whose efforts sculpted an immature specialty into a refined profession. As a man, Tilley's virtue and character stood beyond reproach and was acknowledged by Canada's and Britain's highest honours.

The most valuable lesson that Tilley's legacy offers this generation of medical students and practitioners can be gleaned from his first encounters at East Grinstead. Standing at the bedside of his smouldering patient and assessing the medicines he had at his disposal, Tilley shook his head and resolved to do better; he refused to surrender to the shortcomings of expertise medicine had left him. Tilley grasped the conventional treatments of coagulation therapy, the merits of which were being espoused by experts in the field, and tossed them aside. With a steadfast conviction that his patients deserved a higher level of treatment, Tilley worked tirelessly with McIndoe and hospital staff to produce a revolutionary regimen that ultimately saved the hands, faces and livelihoods of hundreds of men. Tilley's actions at Queen Victoria Hospital serve as a beckoning call of duty for modern day practitioners to greet blatantly deficient aspects of patient care not with resignation, but with the vigour and fortitude that have been proven to make a difference.

ACKNOWLEDGEMENTS: The author is profoundly grateful to Dr Gordon Wilkes of the University of Alberta (Edmonton, Alberta), and Dr Steven Morris of Dalhousie University (Halifax, Nova Scotia) for their generous guidance in the production of this article.

11. Alger EM. On cutaneous burns. Medical Record 1898;53:766-68.

12. Mitchiner PH. Treatment of burns and scalds with special reference to the use of tannic acid. Lancet 1933;233-39.

13. Gordon RM. Treatment of burns by tannic acid. Lancet 1928;336-7.

14. Hunter JB, Gillies H, McIndoe AH, Hudson RV, Colebrook L, Kilner TP. Treatment of burns. Lancet 1940:621-2.

15. McIndoe AH. The misuse of tannic acid. Lancet 1940:627-8.

16. McIndoe AH. Burns of the hands and face. Lancet 1940:655.

17. Andrew DR. The Guinea Pig Club. Aviat Space Environ Med 1994;65:428-33.

18. Feasby WR. The Official History of the Canadian Medical Services, 1939-1945. Department of National Defense, Directorate of History and Heritage 1956:363-6.

19. Cheng H. Firsts in Canadian Plastic and Reconstructive Surgery. University of Toronto, Division of Plastic and Reconstructive Surgery website. 2010 [cited 2011 June 1]. <www.uoftplasticsurgery. $\mathrm{ca} /$ main.php? $\mathrm{p}=1154 \& \mathrm{~s}=1>$ (Accessed July 15, 2012).

20. Douglas LG. History of the Canadian Society of Plastic Surgeons, 1st edn. Quebec: Canadian Society of Plastic Surgeons; 1983.

21. Taylor JR. Canadian Society of Plastic Surgeons: Tribute to our founders. Can J Plast Surg 1997;5:22-32. 